strong editorial board, who have contributed 20 out of the 25 papers so far published, with one (Scheraga) contributing five. Protein chemistry is so broad a subject that the journal does not yet look more well-focused (the Editors' aim) than a general biochemical journal. However, it is well produced, and although no papers are yet noted as 'resubmitted in a revised form. . .', it appears to be carefully edited.
Although none of the first papers struck me as exciting, the journal may well survive and fill a respectable role. This stage has not yet been reached, and it is not at present a serious candidate for funds in any but the very richest of British libraries.

R.P. Ambler is a protein chemist and Reader in Molecular Biology at Edinburgh University.

\section{Immune complexes}

\section{Fred S. Rosen}

Survey of Immunological Research.

Editor-in-chief J.M. Cruse.

Karger. 4/yr. DM308.

Clinical Immunology Reviews.

Editor Ross E. Rocklin.

Dekker. $2 / y$ r. $\$ 45$.

Journal of Clinical Immunology.

Editor Sudhir Gupta.

Plenum. 4/yr. £52.50, \$110.

Lymphokine Research.

Editors Lawrence B. Lachman and

Steven Gillis.

Mary Ann Liebert. 4/yr. $\$ 75$.

Hybridoma.

Editor Zenon Steplewski.

Mary Ann Liebert. 4/yr. \$110.

CARLYLE thought that the invention of movable type created a whole new democratic world and that is probably the more cheerful side of the inundation of immunology literatre that continues to come off the world's presses. The Survey of Immunologic Research tries to encapsulate it all in short surveys, reviews and overviews but the end result is helter-skelter. Very good editors were chosen to monitor their subspecialties and recruit contributions of digestible size on current topics but what has emerged so far defies deglutition and the personal subscription rate for four issues per year, is not cheap.

I have a personal prejudice against the 'camera-ready' format that binds together a bunch of typewritten pages. It always seems unfinished and in need of editing. Marcel Dekker, Inc. has entered another review journal into the arena with Clinical Immunology Reviews at four issues per annum in 'camera-ready' format. On the whole the reviews that have been solicited by Ross Rocklin, the editor, have been of very high quality on 'clinical' topics.

I am no longer certain of what is clinical and what is not, except when it is used as a euphemism for second-rate or trivial. Sudhir Gupta, the editor of another newcomer, the Journal of Clinical Immunology, does not help me with the resolution of my search for a definition of 'clinical' in his introduction of this fourth entry into the cluster of clinical immunology journals. There exists already
Clinical Immunology and Immunopathology and the Journal of Allergy and Clinical Immunology. My feelings of being thwarted by this plethora of journals is perhaps misplaced and a reflection of laziness because this new journal has had original articles of good quality and is obviously filling a need. A personal subscription to this journal, is good value for money.

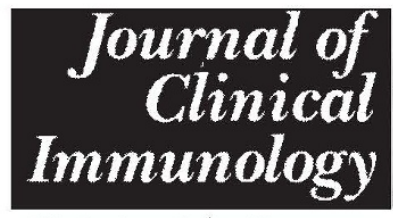

Unfortunately, the same cannot be said for the cost of Lymphokine Research from Mary Ann Liebert. The editors, L.B. Lachman and S. Gillis of Seattle, promise that this little journal will be a 'newsletter' with some summary articles and meeting reports. Lymphokine Research seems to be aimed at a very small coterie of those who seek diligently to clarify the muddy waters of ill-defined factors, or lymphokines if you wish and the contributions to it are of very high quality. The same publisher has scored better with Hybridoma, edited by Zenon Steplewski at the Wistar Institute, Philadelphia with four issues per year. This journal may appeal to a much bigger audience as hybridoma technology gains wider and wider applicability. The contributions to

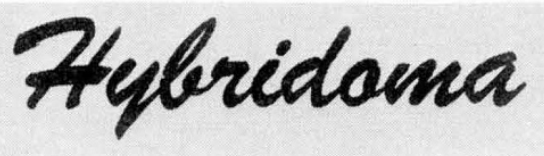

the journals have also been of very high quality and cover the whole range of monoclonal antibodies and their uses. Meeting reports are also summarized in Hybridoma. It might well find a useful niche in every medical library.

"Words, words, words" was Hamlet's terse reply to Polonius when he inquired about the melancholy Dane's reading material. He must have been reading an immunology journal - words, spinning an incredibly complex but orderly web of biologic recognition and response.

Fred S. Rosen is Professor in the Department of Pediatrics, Children's Hospital Medical Centre, Harvard Medical School, Boston.

\section{Connective}

\section{issues}

\author{
Karl A. Piez
}

Collagen and Related Research

Editors-in-chief S. Gay and E.J. Miller

Gustav Fischer. 6/yr. DM218, \$79.

IN THE field of extracellular matrix biochemistry, the only international speciality journal before 1981 was Connective Tissue Research (Gordon \& Breach). It has appeared infrequently (two issues in 1981; two issues and proceedings of a meeting in 1982) and papers usually come from lesser known laboratories. Apparently for these reasons, the publishers and Editors-in-Chief of Collagen and Related Research felt that they could compete for a small but expanding number of papers in the field.

Beginning in December 1980, six issues per year have been published on a regular basis. The list of Editors-in-Chief and Editors reads like a Who's Who in extracellular matrix biochemistry. The journal publishes Original Papers, Brief Reports, Reviews, Current Comments, Announcements (of meetings), Letters to the Editor,

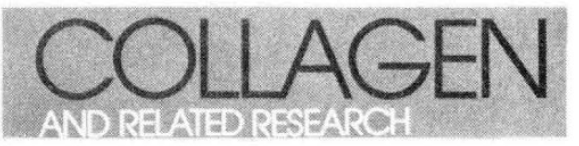

and In Memoriam. Thus, it attempts to be a major means of communication in the field.

The quality of the journal is excellent. Papers are typeset and printed on glossy paper; half-tones are reproduced faithfully. Although received or accepted dates do not appear, publication time appears to be good - about four months from acceptance to publication (E.J. Miller, personal communication) - but delivery in the USA (by surface mail from Europe) may be several months after the publication date. The scope is broad; as many papers on proteoglycans, elastin and glycoproteins appear as on collagen. Disciplines range from protein chemistry through cell and molecular biology to an occasional clinical study. Scientific quality has been kept high, often a difficult achievement for specialty journals.

Like most new journals, Collagen and Related Research has not been widely accepted in major libraries, but it has become a must in smaller departmental libraries where extracellular matrix biochemistry is an important activity. Thus, the journal has carved out a small niche, but for financial reasons it may need to broaden that niche.

Karl A. Piez is Director, Connective Tissue Research Laboratories, Collagen Corporation, Palo Alto. 